\title{
Dialogic-interactive media: Alternative learning media to improve speaking skills
}

\author{
Atmazaki ${ }^{I^{*}}$, Syahrul Ramadhan ${ }^{2}$, Vivi Indriyani ${ }^{3}$, Jeihan Nabila ${ }^{4}$ \\ Fakultas Bahasa dan Seni (FBS), Universitas Negeri Padang, J1. Prof. Dr. Hamka, Air Tawar Bar., Kec. Padang Utara, Kota \\ Padang, Sumatera Barat, Indonesia \\ Iatmazaki@fbs.unpac.id, syahrul_r@fbs.unp.ac.id², vivi.indriyani93@gmail.com³ ,jeihannabila@fbs.unp.ac.id ${ }^{4}$ \\ *Corresponding author: atmazaki@fbs.unpac.id
}

\begin{tabular}{|c|c|c|}
\hline & Revision: October 8, 202I & \\
\hline \multicolumn{3}{|c|}{ ABSTRACT } \\
\hline \multicolumn{3}{|c|}{$\begin{array}{l}\text { The COVID-I9 pandemic has not ended, so the learning process is still being carried out online. This results in ambiguity } \\
\text { about how to teach. Language learning must be able to improve language skills, but some of these skills are difficult to teach. } \\
\text { Based on the survey, speaking skills are the most difficult skills to teach online. Efforts are needed to overcome this, because } \\
\text { speaking is considered the ultimate goal of language learning and the most basic skill to achieve. The purpose of this study } \\
\text { was to develop dialogic-interactive media to improve students' speaking skills. The type of research used is development } \\
\text { research using the Plomp Model (Preliminary Research, Prototype Phase, \& Assessment Phase). Based on the research stages, } \\
\text { the research objectives described in this article are to (I) describe the results of development research at the Preliminary } \\
\text { Research stage and (2) describe the results of development research at the Prototyping Phase. The data analysis technique } \\
\text { used in this research is descriptive data analysis technique. Based on the results of the study, it is shown that the use of } \\
\text { learning methods and media in learning to speak has not helped students to improve their speaking skills. Therefore, } \\
\text { interactive dialogical media were developed (introduction, interactive setting, everyday talk, learning talk, teaching talk, } \\
\text { presenting; questioning; extending) and the teacher had a good response to the media model developed for use in learning } \\
\text { to speak. }\end{array}$} \\
\hline & Copvright@20 & e \\
\hline & \multicolumn{2}{|c|}{ Dialogic-interactive, Speaking skill, Interactive media, Learning media, Dialogic approach } \\
\hline & \multicolumn{2}{|c|}{$\begin{array}{l}\text { Atmazaki, A., Ramadhan, S., Indriyani, V., \& Nabila, J. (202I). Dialogic-interactive media: Alternative } \\
\text { learning media to improve speaking skills. KEMBARA: Jurnal Keilmuan, Bahasa, Sastra dan } \\
\text { Pengajarannya (e-Journal), 7(2), 286-296. https://doi.org/I0.22219/kembara.v7i2.16402 }\end{array}$} \\
\hline
\end{tabular}

\section{INTRODUCTION}

One of the characteristics that distinguishes humans from animals is the ability to speak (Bozkirli, 2019). It is more than a biological activity producing sound using articulation and breathing features but also mental processes. The language that is produced out of the mouth is previously processed in the brain or mind. This, too, suggests that the development of speaking skills is based not only on the maturity of the articulation system but also on the maturity of thought (Zainurrahman \& Sangaji, 2019). Based on this explanation, speaking can be defined as a process that begins with designing in the brain and ends with expressing thoughts through articulation (Türkben, 2019).

Speaking skills are one of the skills that students must master in any language, which aims to communicate in order to express opinions, express feelings, communicate ideas, points of view, hopes, new perspectives and their intentions (Khan, 2019; Maulina, Hikmah, \& Pahamzah, 2019; Alharbi \& Sunur, 2019; Sakka, 2019; Safitri, Akib, \& Hartanti, 2018). Speaking skills are one of the most important language skills required not only for academic purposes but also to address today's global challenges in everyday life (Baresh, Ali, \& Darmi, 2019). It allows students to describe words and their world, understand life experiences, and get things done (Malebese, 2019). This has an impact on one's position in the social and public context, such as the environment of family, friends, and business (Bozkirli, 2019).

Speaking is considered the most important skill in language learning. However, the importance assigned to the classroom is not always coherent with this statement (Javier \& Gómez, 2019). Language 
curriculum overrides the development of speaking skills, as there is not enough time in the curriculum for teachers to develop these skills in the classroom (Kaya, 2019). They focus more on teaching grammar and vocabulary (Fernanda et al., 2019). In addition, although the development of speaking has received attention in language learning (since the beginning of the communicative era), this learning is a complex process including linguistic competence, oral skills, and the use of strategies (Sakka, 2019).

In order to develop effectively, speaking skills need to be developed through education (Bozkirli, 2019). These skills need to be improved by a variety of student-centered methods, as they are organized as language production activities (Sakka, 2019). Teaching strategies or methods must be chosen in line with the program, content and activities. However, most learning methods prioritize speaking as a means of practicing grammar. Most students feel that no matter how well they know grammar and vocabulary, they are not ready to engage in speaking (Aguilar \& Cuellar, 2019). Therefore, it is important to learn speaking skills explicitly in a language classroom through a series of activities by learning speaking knowledge, skills, and strategies (Aguilar \& Cuellar, 2019).

Various methods have been used by teachers to improve students 'speaking performance, but students' competence in speaking is still low. One alternative that can be used in learning to speak is a dialogical approach. Dialogue is more than just 'talk', it is a joint inquiry that bridges the gap between two or more perspectives (Silva, Chigona, \& Adendorff, 2016). It emphasizes dialogue in which students learn to think, discuss, debate, and explain, in order to develop higher-order thinking and articulation (Jay et al., 2017).

Previous research on classroom teaching has shown the positive influence of dialogical teaching on student achievement (Samei, 20I5). It is an effective tool to increase student participation and improve the quality of classroom interactions (Lyle, 20I4). It has the potential to engage students in more interactive patterns of interaction, evaluate ideas, support students to think of their solutions, provide reasons and justify explanations (Siahgorabi, 2018). The use of this approach in learning can increase motivation, involvement, participation, and reasoning (Jay et al., 2017).

In addition to using an appropriate learning approach, so that speaking skills can develop, teachers must make use of available learning resources and not rely solely on textbooks (Zainurrahman \& Sangaji, 2019). Learning media is something that can be used to convey messages (learning material), so that it can stimulate students' attention, interest, thoughts, and feelings in learning activities to achieve learning objectives (Septia, Prahmana, Pebrianto, \& Wahyu, 2018). The use of appropriate learning media is expected to stimulate students' thoughts, concerns and interests so that the learning process can run smoothly and pleasantly (Farizi, Sudiyanto, \& Hartono, 2019).

In response to globalization, the use of technology and the emergence of the Internet in education, public speaking courses have been transformed and teaching techniques have been revolutionized (Salem, 2019; Rahayu, Ramadhan, \& Siregar, 2020). Technology is a vehicle towards modernity and an unavoidable resource in the education sector (Javier \& Gómez, 2019). Applying technology in speaking skills has a positive impact and increases self-confidence (Shamsi, Altaha, \& Gilanlioglu, 2019; Bahadofar \& Omidvar, 2014). Interactive learning facilities are one of the technology facilities commonly used in the learning process (Erişti \& Belet, 2010). Interactive means there is two-way communication and users can respond directly (Muflihah \& Aziz, 2018).

One of the means in interactive learning is learning media. By using interactive media by integrating learning materials, students can be motivated to learn, because they can view text, listen to audio, watch videos, animations and graphics simultaneously (Ampa, 2015). Furthermore, it also serves to distribute, convey, and connect learning resources, which in turn can lead to better communication in learning (Abdulkarim, Ratmaningsih, \& Anggraini, 2018; Munadi, 2008).

Designing and developing interactive learning media must be designed according to the context of their use in order to achieve the goals in the desired way (Derlina, Dalle, Hadi, Mutalib, \& Sumantri, 2018). Learning will be more effective, if it is well designed. This is because students will receive continuous feedback and also help students to achieve the expected competencies (Ampa, 2015). In 
addition, the type of suitable learning media will be influenced by the selection of certain learning methods although there are still many other aspects that must be considered in choosing media (Farizi et al., 2019). Based on this explanation, the research objectives described in this article are to $(\mathrm{I})$ describe the results of development research at the Preliminary Research stage and (2) describe the results of development research at the Prototyping Phase.

\section{METHOD}

This research uses research and development methods. The research model used follows the Plomp model which consists of three phases, namely preliminary research, prototyping phase, and assessment phase (Plomp \& Nienke, 2013). This research was conducted to develop a product, namely interactive-dialogical media to improve learning activities and speaking skills of high school students in learning Indonesian. Based on the research stages, this article will explain the results of the research at the preliminary research stage and the prototyping stage. The data analysis technique used in this research is descriptive data analysis technique. The research instrument is a questionnaire developed with the Google From application and disseminated using WhatsApp media. The questionnaires were in the form of a needs analysis questionnaire filled out by teachers ( 33 respondents), student analysis questionnaires (496 respondents), product validation questionnaires in the form of model books (2 experts), and teacher responses to product questionnaires (33 respondents). Research respondents from students were carried out randomly by distributing questionnaires to all students of various levels in one of the high schools in Padang City. Meanwhile, the research respondents from teachers were conducted randomly by distributing questionnaires to all Indonesian language teachers in West Sumatra. This research was conducted during the COVID-I9 pandemic, so this research was conducted to overcome problems in online learning or distance learning.

\section{RESULT AND DISCUSSIOON}

The research results described in this article are preliminary research and the prototyping phase. The results of these studies are as follows.

\section{Preliminary Research}

In general, the preliminary stage in developing interactive-dialogical media to improve student activity and speaking skills consists of three steps, needs analysis, student analysis, and task analysis. The results of the analysis at this stage are described as follows. First, needs analysis. The stages of this research were carried out by distributing questionnaires to Indonesian language teachers throughout West Sumatra regarding the process of learning to speak in Indonesian language learning. The results of research at this stage can be seen in Table I.

Table I shows that the majority of teachers stated that they did not neglect speaking learning in class. However, their students' speaking skills still need to be improved. Even though the teacher has used various learning methods in learning speaking, it has not helped them in improving students' speaking skills. The results also show that the teacher is a model of speaking in class. This is in accordance with the opinion (Bozkirli, 2019) that the use of accurate and effective speaking skills is the nature of teachers, especially language teachers. So to be a good teacher, one needs a language that is free from speech defects and a psychological state that is free from factors such as anxiety, which will have a negative impact on speaking. 
Tabel I

Need Analysis

\begin{tabular}{|c|c|c|c|c|}
\hline \multirow{2}{*}{ Statement } & \multicolumn{4}{|c|}{ Answer (\%) } \\
\hline & SA & $\mathrm{A}$ & $\mathrm{D}$ & $\mathrm{SD}$ \\
\hline Improving speaking skills is usually neglected in class. & 0 & 15.2 & 45.5 & 39.4 \\
\hline My students' speaking skills need to be improved. & 84.8 & 15.2 & 0 & 0 \\
\hline Teaching speaking skills is more difficult than other language skills. & 21.2 & $5 \mathrm{I} .5$ & 27.3 & 0 \\
\hline Speaking skills must be taught separately, not integrated with other skills. & 15.2 & 27.3 & 39.4 & 18.2 \\
\hline I use a variety of learning approaches to speaking skills. & 42.4 & 57.6 & 0 & 0 \\
\hline $\begin{array}{l}\text { The approach I have used has not helped me in improving my students' speaking } \\
\text { skills. }\end{array}$ & 45.5 & 51.5 & 3.0 & 0 \\
\hline The teacher is a model of speaking in class. & 51.5 & 48.5 & 0 & 0 \\
\hline
\end{tabular}

description: SA (Strongly Agree); A (Agree); D (Disagree); SD (Strongly Disagree)

Second, student analysis. The stages of this research were carried out by distributing questionnaires to high school students in West Sumatra regarding language learning, especially speaking skills. The results of research at this stage can be seen in Table 2 and Table 3.

Tabel 2

Student Response to The Learning Process to Speak

\begin{tabular}{lccc}
\hline \multicolumn{1}{c}{ Statement } & \multicolumn{2}{c}{ Answer $(\%)$} \\
\cline { 2 - 4 } & Yes & No & Maybe \\
\hline In learning speaking, my teacher uses speaking aids (learning media). & 27.8 & 57.7 & I4.5 \\
\hline Learning media makes it easier for me to speak in learning/oral tests. & 60.9 & 4.8 & 34.3 \\
\hline I can easily continue speaking thanks to the learning media. & 56.0 & 6.7 & 37.3 \\
\hline I can use learning media effectively thanks to my group friends. & 61.5 & 26.0 & $\mathrm{I} 2.5$ \\
\hline $\begin{array}{l}\text { The learning media facilitates the learning process when I participate in speaking lessons } \\
\text { with my classmates. }\end{array}$ & 44.4 & 49.2 & 6.5 \\
\hline I can speak easily without learning media. & $\mathrm{I} 5.3$ & 40.9 & 43.8 \\
\hline Learning media are useless. & 3.8 & $\mathrm{I}$ & 7.1 \\
\hline Learning media make me confused. & $\mathrm{I} 0.5$ & 29.6 & 59.9 \\
\hline I forgot what I said because of the learning media. & 6.5 & 44.0 & 49.6 \\
\hline
\end{tabular}


Tabel 3

Students' Speaking Skill Level

\begin{tabular}{|c|c|c|c|c|c|}
\hline \multirow{2}{*}{ Statement } & \multicolumn{5}{|c|}{ Answer (\%) } \\
\hline & $\overline{\mathrm{I}}$ & 2 & 3 & 4 & 5 \\
\hline I was nervous during the learning/speaking test. & 16.9 & 24.4 & 37.7 & I3.I & 7.9 \\
\hline I started to panic when I had to speak unprepared in language class. & 12.9 & $\mathrm{I} 3.5$ & 27.8 & 25.6 & 20.2 \\
\hline When I panic, I can forget things I knew while speaking. & 8.1 & I8.I & 25.2 & 27.6 & 21.0 \\
\hline I could feel my heart pounding when I was called to speak in language class. & 9.7 & 16.7 & 24.6 & 25.4 & 23.6 \\
\hline $\begin{array}{l}\text { I always feel that other students are better than me when learning speaking tests } \\
\text { in language classes. }\end{array}$ & 9.9 & 20.2 & 25.4 & 24.6 & 20.0 \\
\hline $\begin{array}{l}\text { I feel more tense and nervous in language class when I speak than in other } \\
\text { classes. }\end{array}$ & 26.6 & 24.2 & 27.0 & $\mathrm{I} 4.9$ & 7.3 \\
\hline I am afraid that other students will laugh at me when I speak. & 17.5 & 17.7 & 23.6 & 20.0 & 21.2 \\
\hline $\begin{array}{l}\text { I feel nervous when the teacher asks questions that I haven't prepared } \\
\text { beforehand. }\end{array}$ & 5.8 & 10.3 & 24.8 & 30.2 & 28.8 \\
\hline I like to take individual speaking lessons. & 18.5 & 21.6 & 29.8 & $\mathrm{I} 4.7$ & $\mathrm{I} 5.3$ \\
\hline I like to take part in group speaking lessons. & 7.5 & $\mathrm{I} 3.3$ & 25.2 & 23.2 & 30.8 \\
\hline $\begin{array}{l}\text { Speaking individually provides more opportunities to speak freely in learning } \\
\text { to speak. }\end{array}$ & 8.7 & 15.5 & 32.5 & 19.6 & 23.8 \\
\hline $\begin{array}{l}\text { Speaking in groups provides more opportunities to speak freely in learning to } \\
\text { speak. }\end{array}$ & 7.9 & 16.9 & 29.8 & 24.0 & $2 \mathrm{II.4}$ \\
\hline I feel less anxious about speaking if I'm not the only one talking. & 10.5 & I6.I & 31.0 & 27.0 & 15.3 \\
\hline Some students speak more than others in group speaking lessons. & 6.0 & 13.9 & 43.1 & 24.8 & $\mathrm{I} 2 . \mathrm{I}$ \\
\hline $\begin{array}{l}\text { Talking as a group makes me embarrassed by the presence of my classmates in } \\
\text { learning to speak. }\end{array}$ & 34.5 & 26.4 & 23.6 & 9.1 & 6.5 \\
\hline I can't concentrate on group conversation topics because of my group friends. & 28.8 & 28.0 & 26.8 & 9.7 & 6.7 \\
\hline
\end{tabular}

Based on the results of student responses regarding the learning process to speak at this time shows that the teacher is still not maximally using learning media. Even though students stated that the learning media could make it easier for students to learn to speak. The results of student responses indicate that students are still in doubt about the use of instructional media, it may be related to the inadequate use of learning media by their teachers. Interactive learning media can influence the learning process positively as long as they are related to the learning process and content effectively (Eriști \& Belet, 2010). If the media is well designed, learning will be more effective because students will receive continuous feedback. Apart from that, it also helps students to achieve the expected competencies (Ampa, 2015).

Based on the results of the analysis of the students' speaking skills level in table 3, it shows that some students still have problems in the form of speaking anxiety. Anxiety is in the form of feelings of nervousness, panic, heart palpitations, low self-esteem, and tension. Among the four language skills, speaking is the higher skill to correlate with anxiety level (Salem, 2019). Speaking anxiety is one of the psychological barriers that prevent a person from speaking effectively (Addison, Clay, Xie, Sawyer, \& Behnke, 2003). This is a factor affecting fluency in speech, that is, when students are afraid of mistakes, they may hesitate more (Al-Ghazali \& Alrefaee, 2019). A student who thinks they will make mistakes in a classroom activity experiences some level of anxiety. They become anxious, even afraid before speaking out (Oflaz, 2019). High anxiety can cause mental and physical problems such as loss of thinking, restlessness and trembling in the hands and arms, and constant drying of the throat (Bozkirli, 2019).

The anxiety level of the analyzed students was mostly at level 3, which was moderate. However, levels 4 and 5 are still dominant than levels I and 2. The analysis shows that students prefer groups to individuals in learning to speak. The development of speaking skills is determined or at least influenced by the development of social interactions. Speaking activities not only involve the presence of the speaker but also the listener. In a speaking situation, the role of the speaker-listener exchanges in exchange of messages and feedback (Zainurrahman \& Sangaji, 2019). However, some students did not get the 
opportunity to speak because of the tendency of some other students to dominate, while others spoke very little or nothing (Al-Ghazali \& Alrefaee, 2019).

Third, task analysis. Task analysis is a collection of procedures for determining the content in learning units. Task analysis is carried out to detail the learning model with teaching materials in the form of an outline. Task analysis consists of content structure analysis, concept analysis and objective formulation analysis. The explanation regarding the task analysis is as follows. (I) The curriculum used in the development of interactive-dialogical media to improve student learning activities and speaking skills is the 2013 curriculum. (2) The core competencies that will be used in this study are Core Competencies 3 and Competency 4 which require students to speak skillfully. (3) The text used as learning material for this study is seen based on Core competencies. Based on the questionnaire, the text used by the teacher as material to improve speaking skills can be seen in Figure I. (4) The approach/method used by the teacher to improve speaking skills can be seen in Figure 2.

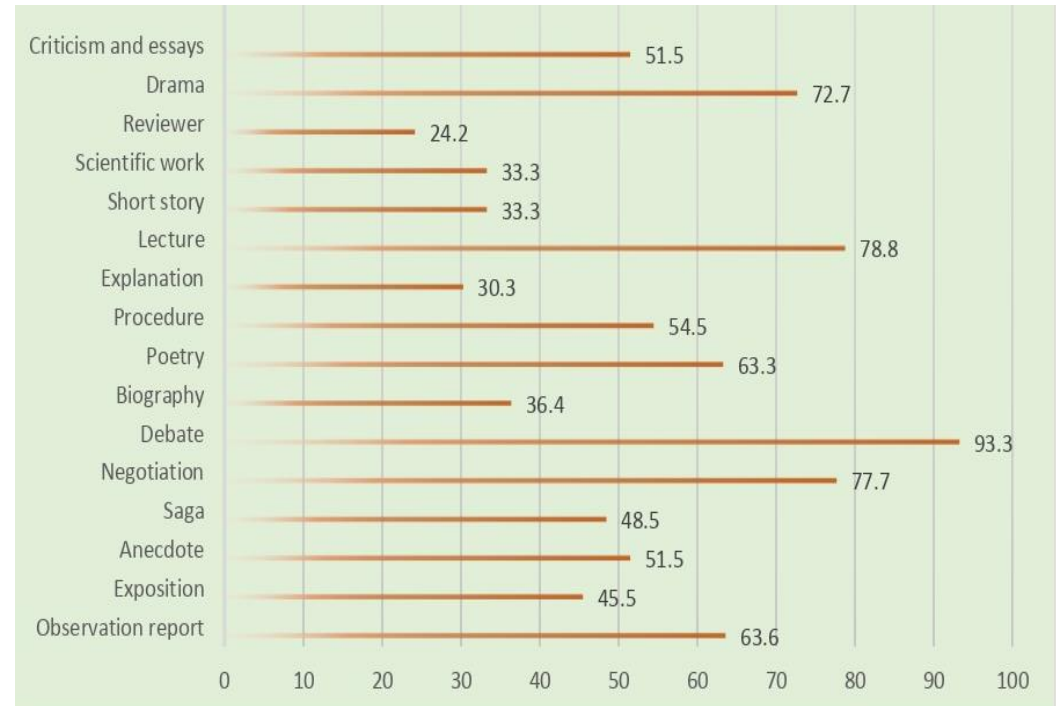

Figure I Types of Text for Learning to Speak

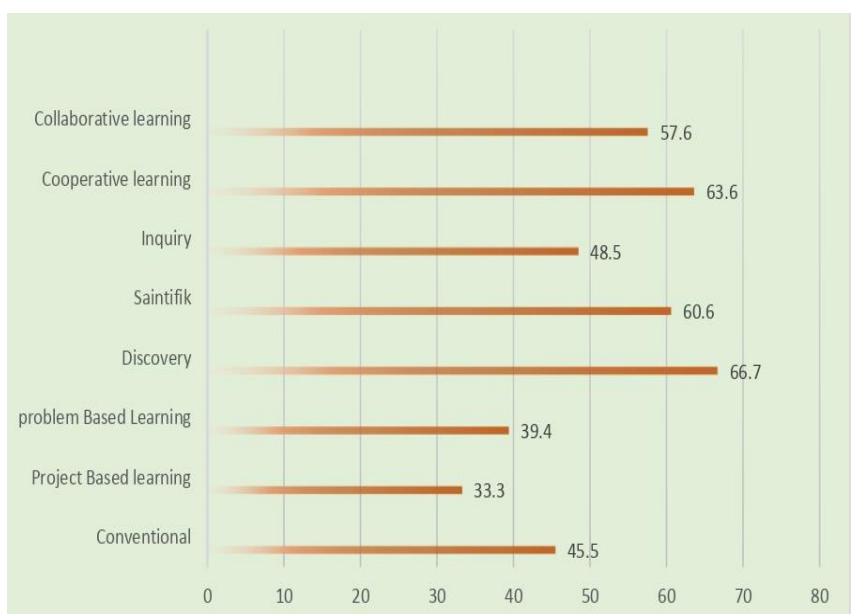

Figure 2 The Approach or Method Used in Learning to Speak

Based on Figure I, it shows that speaking skills can be learned through various genres of text. The text genres that most teachers choose are argumentative text types (debate, negotiation, criticism and essays), literary text types (drama, poetry, saga), and other types of text (observation reports, procedures, lectures).

The choice of one particular learning method will affect the type of learning media that is suitable, 
although there are still many other aspects that must be considered in choosing the media (Farizi et al., 2019). Based on Figure 2, it shows that the approaches most widely used by teachers in improving speaking skills are discovery, cooperative learning, and scientific. Even though the teacher has used a variety of learning approaches, this approach has not been able to improve students' speaking skills. Therefore, dialogic- interactive media was developed as an alternative that teachers can use in language learning to improve student learning skills and activities.

\section{Prototype Phase}

This stage is the stage that is carried out to prepare a dialogic-interactive media prototype for development products to improve learning activities and speaking skills for high school students. Before developing instructional media, a model is developed which will be integrated (as a learning syntax) in the learning media. The integrated dialogic-interactive learning syntax, namely introduction, interactive setting, everyday talk, learning talk, teaching talk, presenting; questioning; extending (Atmazaki, Ramadhan, Indriyani, \& Nabila, 202I).

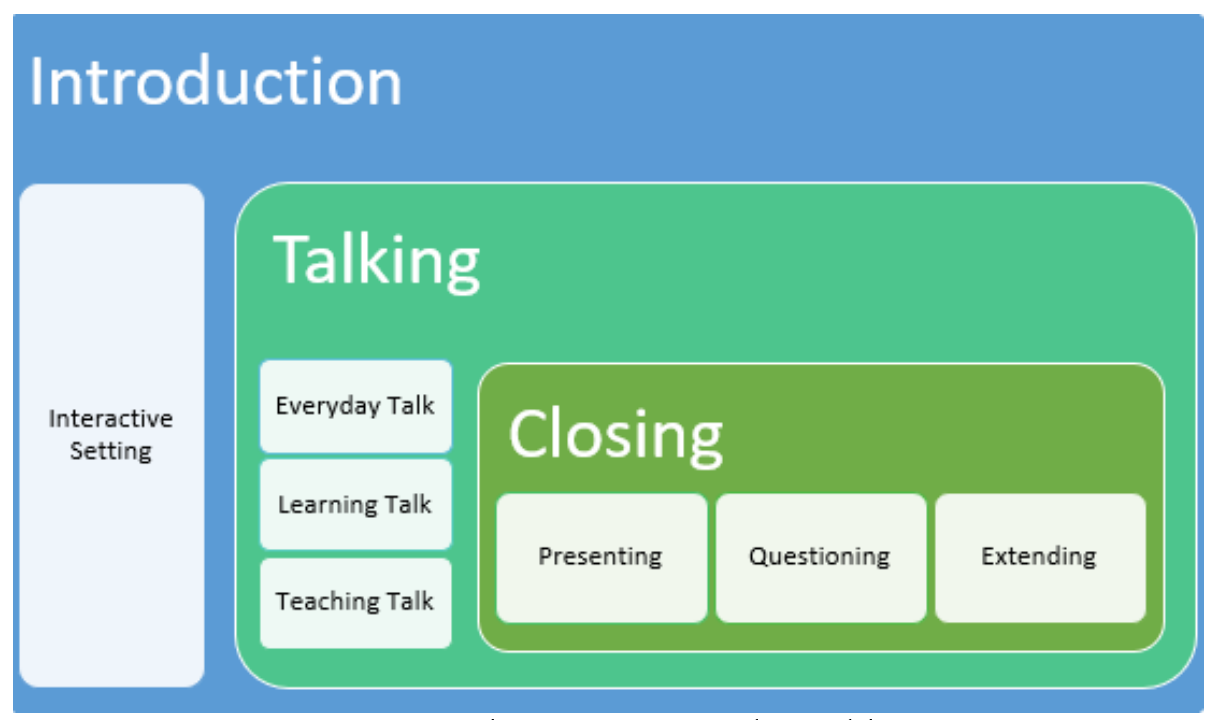

Figure 3 Dialogic-Interactive Media Model

In the early stages of learning, teachers and students must ensure readiness in learning, especially in online learning by preparing learning tools and electronic devices. In the Interactive Setting stage, the teacher determines the interaction modality; determine the learning process (group or individual); learning objectives and types of texts. At the learning stage, speaking will be carried out in three stages (Everyday Talk, Learning Talk, Teaching Talk). At this stage the interactions that occur are dominated by teachers and students. At the Everyday Talk stage, teachers and students interact about daily activities related to the text or learning topic being carried out. At the Learning Talk stage, learning focuses or talks about learning materials. Students can tell, explain, discuss, analyze, and evaluate the learning that has been done. At the Teaching Talk stage, learning focuses on constructing knowledge by expressing opinions that come from students' own thoughts. Next, closing (Presenting, Questioning and Extending). At this stage students improve speaking skills by conducting discussions. Students present something and other students ask questions. This stage occurs interaction between students and students. This lesson ends with providing feedback by reflecting on learning, discussing obstacles that occur in learning, and providing a final explanation. For more details, you can read the following article (Atmazaki, Ramadhan, Indriyani, \& Nabila, 202I).

This Dialogical-Interactive Media Model is a modification of previous research which was developed by several experts and adapted to the needs of students based on needs analysis and literature review found. Elhassan \& Adam (2017) used three steps, namely everyday speech; learn to speak; teaching 
speaking, these steps are used because they are more flexible to use in learning. Gürbüz \& Ağsu (2017) adapted from (AL-Ghazali \& Alrefaee, 2019) using flexibility syntax; Expanders; promote; communication and reflection; \& knowledge structuring. Furthermore, Alexander (2006), (Oflaz, 2019) developed this model with a syntax (interactive settings; everyday talk; learning talk; teaching talk; questioning; and extending).

After developing the syntax, it is validated. Validation is done in three ways (self-evaluation, expert validation, and teacher response). The results of this study can be seen in the following table.

Tabel 4

Validation Result

\begin{tabular}{ccc}
\hline Validation & Score & Category \\
\hline Self Evaluation & 90.84 & Very valid \\
\hline Expert Validation & 90.05 & Very valid \\
\hline
\end{tabular}

Tabel 5

Teachers' Response to The Learning Process to Speak

\begin{tabular}{|c|c|c|c|}
\hline \multirow[t]{2}{*}{ Statement } & \multicolumn{3}{|c|}{ Answer (\%) } \\
\hline & Yes & No & Maybe \\
\hline The model can be applied to the 2013 Curriculum. & 100 & 0 & 0 \\
\hline The right model is used for learning Indonesian Language. & 100 & 0 & 0 \\
\hline The right model is used to improve students' speaking skills. & 97.0 & 0 & 3.0 \\
\hline The appropriate model is used for middle school students. & 97.0 & 0 & 3.0 \\
\hline The syntax sequence in the model is systematic. & 81.8 & 0 & 18.2 \\
\hline The role of the teacher as a facilitator in the model is clear. & 93.3 & 0 & 6.1 \\
\hline The learning model is student-center. & 87.9 & 3 & 9.1 \\
\hline
\end{tabular}

After the model is designed to develop the media, then learning media is developed, namely dialogic- interactive media to be tested in secondary schools. Before being tried out, the learning media must be validated first. Furthermore, it was tried out to get practical value and effectiveness of the developed learning media.

\section{CONCLUSSION}

Based on the results of research and discussion, it is concluded that the needs analysis stage shows that learning to speak is the most difficult learning of other language skills, especially in online learning. Although teachers have used learning media and applied learning approaches to improve students' learning activities and speaking skills, these students' skills must be improved. In addition, learning innovations need to be carried out in accordance with the development of science and technology. One of them is learning media by developing a media model as an alternative in language learning. The model is DialogicInteractive Media which aims to improve students' speaking activities and skills. At the prototyping stage, the product is still in the model development stage to be used as the syntax in the development of learning media. The model is categorized as very valid and the teacher shows a positive response to the model. To find out whether this media model is effective in overcoming the problems found in the needs analysis, it is necessary to test the media model developed for students.

The results of the research at the Premilinary Research stage can be used as a reference by the teacher to determine the needs of students in learning Indonesian, especially to improve students' speaking skills. The developed Dialogic-Interactive Media Model (Prototyping Phase) can be used as an alternative for teachers to develop learning media based on the developed syntax. This media model is recommended for language learning, especially Indonesian language learning for high school students. 


\section{ACKNOWLEDGEMENTS}

The researchers would like to thank the teachers and students who volunteered to be the respondents of this study. Thank you to KEMENRISTEKDIKTI for helping to fund research through the PNBP UNP research fund which was conducted in 2020.

\section{REFERENCES}

Abdulkarim, A., Ratmaningsih, N., \& Anggraini, D. N. (2018). Developing civicpedia as a civic education e-learning media to improve students' information literacy. Journal of Social Studies Education Research, 9(3), 45-6I. Retrieved from https://dergipark.org.tr/en/pub/jsser/issue/43625/534223

Addison, P., Clay, E., Xie, S., Sawyer, C. R., \& Behnke, R. R. (2003). Worry as a function of public speaking state anxiety type. Communication Reports, I6(2), I25-I3I. https://doi.org/I0.1080/08934210309384495

Aguilar, F. C., \& Cuellar, H. O. (2019). Daily 6: An approach to foster oral fluency of English as a foreign language in adolescents. Profile, 2I(2), 29-44. https://doi.org/I0.15446/profile.v2In2.7I364

Alexander, R. (2018). Developing dialogic teaching: Genesis, process trial. Research Papers in Education, 33(5), I-38. https://doi.org/I0.1080/0267I522.2018.I48II40

Al-Ghazali, A., \& Alrefaee, Y. (2019). Silent pauses in the speech of Yemeni EFL learners. ELS Journal on Interdisciplinary Studies on Humanities, 2(I), 39-48. http://dx.doi.org/10.2139/ssm.3363215

Alharbi, A. F., \& Sunur, R. S. (2019). The effectiveness of oral assessment techniques used in efl classrooms in Saudi Arabia from students and teachers point of view. English Language Teaching, I2(5), I-9. Retrieved from https:// eric.ed.gov/?id=EJI2I240I

Ampa, A. T. (2015). The implementation of interactive multimedia learning materials in teaching listening skills. English Language Teaching, 8(I2), 56-62. Retrieved from https://eric.ed.gov/?id=EJI084334

Atmazaki, Ramadhan, S., Indriyani, V., \& Nabila, J. (202I). Dialogic-interactive media design for language learning to improve speaking activities and skills. In 2nd Bukittinggi International Conference on Education (BICED) 2020 (pp. I-9). IOP Publishing.

Bahadofar, M., \& Omidvar, R. (20I4). Technology in teaching speaking skill. Acme International Journal of Multidisciplinary Research, $I I(\mathrm{IV}), 9-\mathrm{I} 3$.

Baresh, E. F., Ali, S. M., \& Darmi, R. (2019). Using hybrid Problem-based Learning (HPBL) approach to enhance Libyan EFL students' engagement with English language. Intrnational Journal of Education \& Literacy Studies, 7(2), 9-20. Retrieved from https:/ / eric.ed.gov/?id=EJI2I 9596

Bozkirli, K. C. (2019). An analysis of the speaking anxiety of Turkish teacher candidates. Journal of Education and Training Studies, 7(4), 79-85. Retrieved from https://eric.ed.gov/?id=EJI2I0822

Derlina, Dalle, J., Hadi, S., Mutalib, A. A., \& Sumantri, C. (2018). Signaling principles in interactive learning media through expert's walktrough. Turkish Online Journal of Distance EducationTOJDE, I9 4), I47-I62. I0.I77I8/tojde.47I9II

Elhassan, I. B. M. \& Adam, M. I. (20I7). The impact of dialogic teaching on english language learners speaking and yhingking skills. Arab World English Journal, 8(4), 49-67.

Erişti, S. D., \& Belet, Ş. D. (20I0). Teachers' and students' opinions about the interactive instructional environment designed for bilingual Turkish primary school students in Norway. Turkish Online Journal of Qualitative Inquiry, I(I), 30-48. http:/ / dx.doi.org/I0.2I39/ssm.3094525

Farizi, M. F. Al, Sudiyanto, \& Hartono. (2019). Analysis of Indonesian language learning obstacles in primary schools. International Journal of Educational Methodology, 5(4), 663-669. https://doi.org/I0.12973/ijem.5.4.663 
Fernanda, M., Osorio, J., Catalina, M., Muñoz, C., Camilo, I., \& Bohórquez, T. (2019). A radio program : A strategy to develop students' speaking and citizenship skills. HOW, 26(I), 8-33.

Gürbüz, M. C. \& A $\breve{g}_{s u}$ M. (20I7). Dialogic teaching model for ninth class students to conceptualiza inequalities. Journal Education Practice, 8(28), I7I-I87. Retrieved from https:/ / eric.ed.gov/?id=ED582086

Javier, J., \& Gómez, C. (2019). Multimedia resources and their incidence in the English speaking skill Publication.

Jay, T., Willis, B., Thomas, P., Taylor, R., Burnett, C., Merchant, G., \& Stevens, A. (2017). Dialogic teaching: Evaluation report and executive summary. UK: Sheffield Halla University.

Kaya, S. (2019). A comparison between the fifth grade intensive English Language curriculum and the fifth grade English language curriculum: Students' achievement in speaking. European Journal of Educational Research, 8(4), 92I-933. Retrieved from https://eric.ed.gov/?id=EJI23I573

Khan, J. U. (2019). Post-secondary Arabian gulf students and their state of English: Common grammatical, spelling, and pronunciation errors. International Journal of Linguistics, Literature and Translation (IJLLT), 2(I), I-2. Retrieved from https://www.alkindipublisher.com/index.php/ijllt/article/view/325

Lyle, S. (20I4). Dialogic teaching: Discussing theoretical contexts and reviewing evidence from Classroom Practice. Language and Education, 22, 222-240. https://doi.org/I0.2167/le778.0

Malebese, M. L. (2019). A socially inclusive teaching strategy: A liberating pedagogy for responding to English literacy problems. South African Journal of Education, 39(I), I-9. I0.I5700/saje.v39nIaI5I4

Maulina, U., Hikmah, S., \& Pahamzah, J. (2019). Attractive learning media to cope with students' speaking skills in the industry 4.0 using sparkol videoscribe. International Journal of Linguistics, Literature and Translation (IJLLT), 2(5), I32-I40. Retrieved from https:/ / eric.ed.gov/?id=ED598724

Muflihah, \& Aziz, H. (2018). Developing interactive multimedia cd-based teaching materials for teaching arabic skill at arabic education department of Islamic State University Sunan Ampel Surabaya. Dinamika Ilmu, I8(2), I95-2I0. Retrieved from http://books.uinsby.ac.id/id/eprint/556/

Munadi, Y. (2008). Media Pembelajaran. Ciputat: Gaung Persada (GP) Press.

Oflaz, A. (2019). The foreign language anxiety in learning German and the effects of total physical response method on students' speaking skill. Journal of Language and Linguistic Studies, I5(I), 70-82. https:/ / doi.org/I0.17263/j11s.5476I6

Plomp, T., \& Nienke. (2013). Educational design research: An introduction. In T. P. \& N. Nieveen (Ed.), Educational design research - Part A: An Introduction (pp. 10-5I). Enschede, the Netherlands: SLO.

Rahayu, P., Ramadhan, S., Siregar, S. D., Jufrizal, Rozimela, Y., Indriyani, V., ... Atmazaki. (2020). Teaching Speaking Through Techno Driven Task (Zig Zag Task) Teaching Speaking Through Techno Driven Task ( Zig Zag Task ). In IOP Conf. Series: Journal of Physics: Conf. Series I47I (2020) (pp. I-7). Retrieved from https://iopscience.iop.org/article/I0.I088/I7426596/I47I/I/0I205I/meta

Safitri, A. R., Akib, M., \& Hartanti, R. (2018). The use of group investigation method to improve students' speaking ability at English department of Sorong Muhammadiyah University. Qalam: Jurnal Ilmu Kependidikan, 6(2). https://doi.org/I0.33506/jq.v6i2.2I6

Sakka, S. M. F. El. (2019). Explicit affective strategy instruction to develop speaking performance of Egyptian EFL university students. English Language Teaching, I2(4), 85-95. https://doi.org/I0.5539/elt.vI2n4p85

Salem, A. A. M. S. (2019). A sage on a stage, to express and impress: TED talks for improving oral presentation skills, vocabulary retention and its impact on reducing speaking anxiety in ESP settings. English Language Teaching, I2(6), I46-I60. Retrieved from 
https://eric.ed.gov/?id=EJI2I669I

Samei, B. et al. (2015). Modeling classroom discourse: do models that predict dialogic instruction properties generalize across populations? In Proceedings of the 8th International Conference on Educational Data Mining (pp. 444-447).

Septia, T., Prahmana, R. C. I., Pebrianto, \& Wahyu, R. (2018). Improving students spatial reasoning with course lab. Journal on Mathematics Education, 9(2), 327-336. Retrieved from https:/ / eric.ed.gov/?id=EJI I 943 I6

Shamsi, A. F., Altaha, S., \& Gilanlioglu, I. (2019). The role of m-learning in decreasing speaking anxiety for EFL learners. International Journal of Linguistics, Literature and Translation (IJLLT), 2(I), 276-282. Retrieved from https://eric.ed.gov/?id=ED593436

Siahgorabi, S. H. (2018). Maintaining productive patterns of teacher-student interactions in mathematics classrooms. In Proceedings of the 4Ist annual conference of the Mathematics Education Research Group of Australasia (pp. 369-375).

Silva, C. R. de, Chigona, \& Adendorff, S. A. (2016). Technology integration: Exploring interactive whiteboards as dialogic spaces in the foundation phase classroom. TOJET: The Turkish Online Journal of Educational Technology, I5(3), I4I-I50. Retrieved from http://digitalknowledge.cput.ac.za/handle/I I I89/7387

Türkben, T. (2019). The effects of interactive teaching strategies on speaking skills of students learning Turkish as a second language. Journal of Language and Linguistic Studies, I5(3), I0I I-I03 I. Retrieved from https://dergipark.org.tr/en/pub/j1ls/article/63I546

Zainurrahman, \& Sangaji, S. (2019). A study the university students' speaking difficulties. LanguaJournal of Linguistics, Literature, and Language Education, 2(I), I-8. 